\title{
Responses of microphytobenthos to light: primary production and carbohydrate allocation over an emersion period
}

\author{
R. G. Perkins ${ }^{1}$, G. J. C. Underwood ${ }^{1, *}$, V. Brotas ${ }^{2}$, G. C. Snow ${ }^{1,3}$, B. Jesus ${ }^{2}$, L. Ribeiro ${ }^{2}$ \\ ${ }^{1}$ Department of Biology, John Tabor Labs., University of Essex, Wivenhoe Park, Colchester, Essex CO4 3SQ, United Kingdom \\ ${ }^{2}$ Instituto de Oceanographia, Faculdade de Ciências da Universidade de Lisboa, Campo Grande, Lisboa, Portugal \\ ${ }^{3}$ Department of Botany, University of Port Elizabeth, PO Box 1600, Port Elizabeth, 6000, South Africa
}

\begin{abstract}
The effect of high (ambient) and low (shaded to $50 \%$ of ambient) light on microphytobenthic biofilm primary production, vertical migration and allocation of photoassimilated carbon into extracellular carbohydrates was investigated over the low tide emersion period at Sarilhos Pequenos on the Tagus estuary, Portugal, in July 2000. Carbon uptake $\left({ }^{14} \mathrm{C}\right.$ measurements), electron transport (pulse-amplitude modulated [PAM]-fluorescence) and carbon allocation into extracellular carbohydrate fractions were measured. There was a decrease in the maximum rate of primary production $\left(P_{\max }\right)\left({ }^{14} \mathrm{C}\right)$ over the emersion period $\left(16\right.$ decreasing to $5 \mathrm{mg} \mathrm{C} \mathrm{m}^{-2} \mathrm{~h}^{-1}$ at midday and the end of emersion, respectively) that was independent of the incident light and the light history to which the biofilms had been exposed. Primary production $\left({ }^{14} \mathrm{C}\right)$ did not correlate with measurements of in situ relative electron transport rate (rel.ETR), due in part to the light-induced migration of the cells away from the sediment surface during periods of high irradiance (photosynthetic photon flux density [PPFD] $\left.>1200 \mathrm{~mol} \mathrm{~m}^{-2} \mathrm{~s}^{-1}\right)$. Downward migration coincided with the light level at which $P_{\max }\left({ }^{14} \mathrm{C}\right)$ was reached, $750 \mathrm{~mol} \mathrm{~m}^{-2} \mathrm{~s}^{-1}$, and with a point of inflexion on the rel.ETR versus PPFD curve. Above this light level rel.ETR was over-estimated due to migration of the cells into a lower light field in the sediment. Shading significantly increased the extracellular polymeric substance (EPS) production rate (from 0.4 to $1.0 \mathrm{mg} \mathrm{C} \mathrm{m}^{-2} \mathrm{~h}^{-1}$ in ambient and shaded light, respectively) and percentage allocation of photoassimilates into EPS (from $4 \pm 1.0$ to $18 \pm 3.5 \%$ of total production in ambient and shaded light, respectively). In contrast, percentage allocation of photoassimilates to low molecular weight extracellular carbohydrate was higher in the non-shaded treatments $(35 \pm 4.5 \%$ compared with $13 \pm$ $3.8 \%$ in ambient and shaded treatments, respectively), probably due to photosynthetic 'overflow'. In non-shaded biofilms there was little or no increase in the concentration of all extracellular carbohydrate fractions until the last hour before tidal immersion. Results indicate that diel patterns in microphytobenthic primary production are not predictable solely from light data.
\end{abstract}

KEY WORDS: Microphytohenthos $\cdot$ Primary production $\cdot$ Carbohydrates $\cdot$ EPS $\cdot$ Fluorescence

\section{INTRODUCTION}

Microphytobenthic biofilms in estuarine sediments exhibit high rates of primary production (Brotas \& Catarino 1995, Underwood \& Kromkamp 1999) and can make a substantial contribution to the carbon flow in intertidal sediments (Underwood \& Kromkamp 1999,

*E-mail: gjcu@essex.ac.uk
Middelburg et al. 2000). In temperate latitudes, intertidal biofilms can be exposed to high temperatures $\left(>30^{\circ} \mathrm{C}\right.$; Blanchard et al. 1996) and irradiances (exceeding $2000 \mu \mathrm{mol} \mathrm{m} \mathrm{m}^{-2} \mathrm{~s}^{-1}$ ), especially when tidal emersion periods correspond with solar maxima in summer. Experimental work using sediment slurries has indicated that the maximum rate of biomass-normalised primary production $\left(P^{*}{ }_{\text {max }}\right)$ is greatest at $25^{\circ} \mathrm{C}$, and at temperatures above this, $P^{*}{ }_{\max }$ declines (Blan- 
chard et al. 1996). At high irradiances, motile microphytobenthos move down into the sediment away from the sediment surface, a behaviour that alters the profile of oxygen production within the sediment surface and the vertical layering of various taxonomic groups of microalgae (Paterson et al. 1998, Underwood \& Kromkamp 1999).

The ability of microphytobenthos to migrate vertically within the surface sediment may be considered as a form of behavioural photoacclimation, allowing cells to avoid potentially damaging irradiance and temperature conditions. It has been suggested that these 'micro-migrations' result in biofilms maintaining high rates of primary production, as cells constantly cycle through the high light zone of the sediment but move away before photodamage can occur (Kromkamp et al. 1998). If micro-migration is a major adaptation allowing continuous high rates of photosynthesis within a biofilm, one would hypothesise that estuaries at lower latitudes, if similar in other respects (nutrient loads, sediment types), would have higher annual rates of production than those at higher latitudes, due to the greater light availability. Yet this does not appear to be so, with estimates from southern Europe (Tagus estuary, $38^{\circ} \mathrm{N}$ ) not differing in any great extent from those of northwest Europe (Brotas \& Catarino 1995, Underwood \& Kromkamp 1999, Serôdio \& Catarino 2000). Possibly, increased light availability is offset by the deleterious effects of higher irradiances and temperatures, such that primary production is suppressed in high light situations (Guarini et al. 1997, Blanchard \& Guarini 1999, G.J.C.U. unpubl. data).

Pulse-amplitude modulated (PAM) fluorescence is a non-invasive technique that measures the efficiency of photochemistry at PSII (Genty et al 1989, Oxborough et al. 2000) and can be used to repeatedly measure sediment slurries (Hartig et al. 1998) and intact microphytobenthic biofilms (Kromkamp et al. 1998, Underwood et al. 1999, Barranguet \& Kromkamp 2000). Provided that certain criteria can be ascertained (Oxborough et al. 2000, Perkins et al. in press), the electron transport rate (ETR) can be calculated (Sakshaug et al. 1997), which can be compared with other measurements of photosynthetic primary production (Hartig et al. 1998, Kromkamp et al. 1998, Barranguet \& Kromkamp 2000).

In addition to short-term responses to light, microphytobenthic biofilms exhibit endogenous rhythms of vertical migration, with the arrival of cells at the sediments' surface synchronised to daytime tidal exposures (Serôdio et al. 1997, Paterson et al. 1998, Smith \& Underwood 1998, Underwood \& Kromkamp 1999). Benthic diatoms, which are usually the major constituents of intertidal microphytobenthos (Underwood \& Kromkamp 1999), move through the production of extracellular polymeric substances (EPS), of which carbohydrates are a major component (Hoagland et al. 1993, Smith \& Underwood 1998, 2000). The presence of EPS increases the critical shear stress required to erode sediments (Paterson 1994, Widdows et al. 2000), as well as serving as a carbon source to the sediment community (Underwood \& Smith 1998, Decho 1990, Middelburg et al. 2000, van Duyl et al. 2000). The allocation of carbon by benthic diatoms to different extracellular carbohydrate fractions varies depending on a number of factors. EPS production rate and sediment EPS concentrations increase just before tidal immersion, when the cells begin to migrate down (Smith \& Underwood 1998, Taylor et al. 1999). Light intensity also changes the proportions and the amounts of high molecular weight (EPS) to low molecular weight (LMW) material excreted. Some studies showed an increase in the proportion and production rates of EPS during lower irradiances, with higher amounts of LMW carbohydrates produced at high irradiances (Smith \& Underwood 1998, 2000, van Duyl et al. 1999, G.J.C.U. unpubl. data), while other studies have concluded that EPS production is a purely phototrophic processes, used as an 'overflow' for excess photoassimilates (Staats et al. 2000).

This study set out to investigate the response of intertidal biofilms to high light conditions by experimentally shading areas of mudflat to reduce light intensity. Our hypothesis was that high irradiances reduce the active microphytobenthic biomass at the surface, resulting in decreased rates of photosynthesis and increased allocation of carbohydrates in EPS pools. A combination of in situ techniques (PAM fluorescence to measure PSII photochemical efficiency, ${ }^{14} \mathrm{C}$ incorporation) were used to measure the photosynthetic properties of the surface-active biofilms over the low tide emersion. These measurements were coupled with time course measurements of sediment carbohydrate concentrations and carbon allocation $\left({ }^{14} \mathrm{C}\right)$ into different extracellular carbohydrate fractions (Smith \& Underwood 1998) during the course of a tidal exposure period in both high and low light biofilms. Such a combined approach allows both changes in standing stock and fluxes of carbohydrate material through different sediment pools to be established.

\section{METHODS}

Site description and sampling program. All field work was carried out at Sarilhos Pequenos on the southern side of the Tagus estuary $\left(38^{\circ} 44^{\prime} \mathrm{N}\right.$, $\left.09^{\circ} 08^{\prime} \mathrm{W}\right)$, Lisbon, Portugal, on 6 and 12 July 2000. The Tagus is a mesotidal estuary bordered mainly by mudflats, with a mean depth of $5 \mathrm{~m}$ (Brotas \& PlanteCuny 1998). Sarilhos Pequenos has extensive mudflats, a tidal height of $2.7 \mathrm{~m}$ and an immersion period of $34 \%$ 
of the time. On 6 July, six $2 \mathrm{~m}^{2}$ areas of sediment were marked out on the upper mudflat at Sarilhos Pequenos. Three sample areas were shaded with neutral density muslin on a wooden frame raised $0.5 \mathrm{~m}$ above the sediment, reducing the ambient light by approximately $50 \%$. The remaining 3 sites had wooden frames without the muslin and so received ambient irradiance. Shading commenced at the start of the low tide emersion at 10:00 h.

Sediment carbohydrate concentrations were measured in 5 sets of samples from each treatment taken over the $6.5 \mathrm{~h}$ emersion period, with paired subsamples used for chlorophyll a ( $\mathrm{chl} a$ ) measurement of algal biomass.

Primary production was measured in situ in each sample area ( $\mathrm{n}=3$ per treatment) at midday (12:00 to $12: 45 \mathrm{~h}$ ) and at the end (16:00 to $16: 45 \mathrm{~h}$ ) of the emersion period. Light response curves from ${ }^{14} \mathrm{C}$ radiotracer and PAM fluorescence data were obtained at 5 light levels: ambient and 4 lower irradiances adjusted by layers of muslin sheeting in small wooden frames. Paired measurements of ${ }^{14} \mathrm{C}$ primary production rate, ${ }^{14} \mathrm{C}$ carbohydrate labelling, PAM fluorescence and chl a were made under each light level. For the first set of measurements at 12:00 to $12: 45 \mathrm{~h}$, light curves were carried out on sample areas that had had no prior shading for either treatment and data were pooled $(n=6)$. During the second set of measurements, 3 replicates had been shaded from 10:00 h $(\mathrm{n}=3)$. Three replicate light curves for each treatment were thus obtained for ${ }^{14} \mathrm{C}$ radiotracer and PAM fluorescence measurements. The second sampling period measured the changes in primary production and carbohydrate allocation compared with midday values, as well as the differences between shaded and non-shaded treatments.

Ambient irradiance was measured every 15 min using a cosine-corrected quantum sensor, in addition to the quantum sensor attached to the PAM fluorimeter. Sediment temperature measured with a digital thermometer was logged on 5 occasions. Pore water and surface-water salinity were measured using a refractometer. ${ }^{14} \mathrm{C}$ and carbohydrate sediment samples were sub-sampled for paired measurement of $\mathrm{chl} a$. Chl a was extracted from freeze-dried sediment over $24 \mathrm{~h}$ in cold methanol and chl a content was corrected for phaeophorbide type pigments by acidification with $10 \% \mathrm{HCl}$ (Lorenzen 1967).

Carbohydrate fractions. Sediment samples $(2 \mathrm{~mm}$ depth) were freeze-dried, with known weights of subsample used in extractions for each carbohydrate fraction and chl a. Samples were taken 5 times over the emersion period. Total sediment carbohydrate concentration and carbohydrate fractions, defined as colloidal-S (water-soluble), EPS and LMW, were measured using the methods of Underwood et al. (1995) and Smith \& Underwood (1998). Colloidal-S carbo- hydrate was defined as the fraction extracted by saline at $20^{\circ} \mathrm{C}$. EPS is the fraction of colloidal-S carbohydrate precipitated by $70 \%$ ethanol. LMW carbohydrate was calculated by difference as colloidal-S minus the EPS concentration. Fractions were quantified using the phenol-sulphuric acid assay (Dubois et al. 1956) as milligrams of glucose equivalents $\mathrm{m}^{-2}$ using a D-glucose standard curve. Paired measurements of chl a were made as described above for determination of diatom carbohydrate to chl a ratios.

${ }^{14} \mathrm{C}$ radiotracer measurements. Total primary production $\left(\mathrm{mg} \mathrm{C} \mathrm{m}^{-2} \mathrm{~h}^{-1}\right.$ ) and primary productivity ( $\mu \mathrm{g} \mathrm{C}$

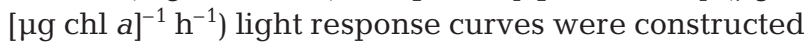
from measurements at the start and end of the emersion period. In addition, hourly production rates of colloidal-S carbohydrate, EPS and LMW carbohydrate were measured from sub-samples of ${ }^{14} \mathrm{C}$-labelled biofilm. Sediment cores (internal area $3.14 \mathrm{~cm}^{2}$ ) were incubated in situ with labelled ${ }^{14} \mathrm{C}$ sodium bicarbonate. One millilitre (370 Bq) of label was added to each core and allowed to diffuse in the dark for $45 \mathrm{~min}$. After dark diffusion (Smith \& Underwood 1998) a $45 \mathrm{~min}$ incubation at 5 light levels was carried out and terminated by addition of $5 \%$ gluteraldehyde. Sediment samples were freeze-dried and divided into 2 subsamples. One set of samples was used for primary production measurements and had inorganic label driven off by addition of concentrated $\mathrm{HCl}$ for $24 \mathrm{~h}$. After addition of scintillant cocktail (Optiphase Safe, Fisons, Loughborough, UK), carbon uptake rates were calculated from counts obtained from a Packard Tricarb 460C scintillation counter (LKB, Cambridge, UK) with internal quench correction. Counts were corrected for self-quenching by the sediment using radiation standard curves with and without sediment addition. Selfquenching reduced counts by 2 to $5 \%$. From the remaining sub-samples of sediment, ${ }^{14} \mathrm{C}$-labelled colloidal-S carbohydrate and EPS were extracted as above and production rates $\left(\mu \mathrm{g} \mathrm{C}\right.$-carbohydrate $\mathrm{m}^{-2}$ $\mathrm{h}^{-1}$ ) were calculated from scintillation counts in liquid phase extracts obtained from these fractions treated in the same way as for the total primary production measurements. Percentage incorporation of carbon into colloidal-S, EPS and LMW carbohydrate fractions were calculated as proportions of the total primary production data.

Fluorescence measurements. In situ fluorescence was measured with a Diving-PAM fluorimeter (Walz, Effeltrich, Germany). Light response curves for the efficiency of photochemistry at PSII $\left(F_{\mathrm{q}}{ }^{\prime} / F_{\mathrm{m}}{ }^{\prime}\right.$, where $F_{\mathrm{q}}{ }^{\prime}$ is fluorescence yield of PSII quenched by photochemistry and $F_{\mathrm{m}}{ }^{\prime}$ is the maximal fluorescence in the lightadapted state; Oxborough et al. 2000) and relative electron transport rate (rel.ETR) were obtained in parallel to the ${ }^{14} \mathrm{C}$ radiotracer light curves using the same 
light range described above. Rel.ETR was calculated as the product of $F_{\mathrm{q}}{ }^{\prime} / F_{\mathrm{m}}{ }^{\prime}$ and irradiance (PPFD/2, where PPFD is photosynthetic photon flux density), following Sakshaug et al. (1997). Light response curves of rel.ETR versus PPFD were compared with primary production. The light-saturated maximum rate $\left(\right.$ rel.ETR $\left.R_{\max }\right)$ and the maximum light utilisation coefficient $(\alpha)$ were determined by iterative solution of the light response curve (Long \& Hällgren 1993).

Fluorescence measurements of migration. Vertical migration of microphytobenthos was analysed using PAM fluorescence on 12 July 2000 at the same sample site. Fluorescence parameters were measured for 5 replicates in ambient light and 5 replicates initially in ambient light and then shade-adapted for $15 \mathrm{~min}$. Data were analysed by examining changes in the lightadapted fluorescence just before the saturating pulse $\left(F^{\prime}\right)$ and $F_{\mathrm{q}}{ }^{\prime} / F_{\mathrm{m}}{ }^{\prime}$ to monitor vertical migration and changes in photochemical efficiency. An increase in $F^{\prime}$ despite decreasing light level and with the fluorimeter probe at a constant distance above the sediment would indicate a vertical migration of cells towards the surface of the biofilm.

Five sets of measurements were taken (Table 1). At time (T) 1, light-adapted measurements were made before any treatment $(n=10)$. At T2, dark-adapted measurements were made after 15 min of dark adaptation $(\mathrm{n}=10)$. Shading was then applied to 5 replicates for 15 min, reducing the ambient light to $25 \%$, after which light-adapted measurements were taken to compare the ambient with the shaded biofilms $(n=5)$. Dark-adapted measurements were then repeated (T4) but without pooling of the 2 sets of replicates $(n=5)$ due to the different light histories, again to compare the ambient with the shaded treatments. Shading was then removed and light-adapted (T5) and dark-adapted measurements (T6) were repeated $(n=5)$. Finally a last set of lightadapted measurements were taken (T7). Relative changes in fluorescence parameters were compared.
Statistical analysis. Primary production, carbohydrate and chl a data were tested for heteroscedasticity by Bartlett's test and where necessary data were log transformed $\left[x^{\prime}=\log (x+1)\right]$ (Zar 1996). Fluorescence data were arcsine transformed $\left[x^{\prime}=\arcsin (\sqrt{x})\right]$ before analysis. Two-factor ANOVA was used to test for significant variation of data. Correlation analysis was carried out to identify possible interactions between data.

\section{RESULTS}

\section{Physical data}

Ambient light increased from 1100 to $1600 \mathrm{\mu mol} \mathrm{m}^{-2}$ $\mathrm{s}^{-1}$ PPFD from 09:45 to 11:45 h (Fig. 1a), with the shaded treatment reducing this to an increase from 740 to $910 \mu \mathrm{mol} \mathrm{m}{ }^{-2} \mathrm{~s}^{-1}$ PPFD. Irradiance then remained stable before declining after 14:20 h. Shading reduced the temperature by approximately $4^{\circ} \mathrm{C}$, with a range of 25 to $27^{\circ} \mathrm{C}$ in the shade compared with 27.5 to $31^{\circ} \mathrm{C}$ in the ambient light (Fig. 1a). There was little difference in salinity between the 2 treatments, with ranges of 33.3 to 37.7 in the ambient light compared with 34.0 to 36.0 in the shaded treatment (Fig. 1a).

\section{Chlorophyll a}

Sediment chl a content (Fig. 1b) was significantly higher in the ambient light than in the shade $\left(F_{2(1,40)}=\right.$ $5.81, \mathrm{p}<0.05$ ) and increased significantly over the emersion period in both ambient light and in the shade $\left(F_{2(4,40)}=3.17, \mathrm{p}<0.05\right)$. In ambient light, chl $a$ in-

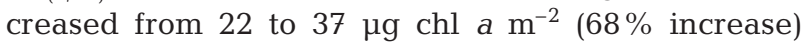
before declining at the end of the emersion period, compared with an increase from 22 to $30 \mu \mathrm{g} \mathrm{chl} \mathrm{a} \mathrm{\textrm {m } ^ { - 2 }}$ $(36 \%)$ with no subsequent decrease in the shade.

Table 1. Summary of fluorescence measurements taken on 12 July 2000 at Sarilhos Pequenos, Portugal, for the vertical migration experiment. $F^{\prime}$ : light adapted fluorescence just before the saturating pulse; $F_{\mathrm{m}}$ ': maximal fluorescence in the light-adapted state; $F_{0}{ }^{15}$ : minimal fluorescence after 15 minutes dark adaptation; $F_{\mathrm{q}}{ }^{\prime}$ : fluorescence yield of PSII quenched by photochemistry $\left(F_{\mathrm{q}}{ }^{\prime}=\right.$ $\left.F_{\mathrm{m}}{ }^{\prime}-F^{\prime}\right) ; F_{\mathrm{v}}$ : variable fluorescence in the dark-adapted state $\left(F_{\mathrm{v}}=F_{\mathrm{m}}-F_{0}{ }^{15}\right) ; \mathrm{T}$ : time

\begin{tabular}{|c|c|c|c|c|}
\hline \multirow[t]{2}{*}{ Time } & \multirow[t]{2}{*}{ Treatment } & \multirow[t]{2}{*}{$\begin{array}{l}\text { Fluorescence } \\
\text { measurements }\end{array}$} & \multicolumn{2}{|c|}{$\begin{array}{l}\text { Calculated } \\
\text { parameter }\end{array}$} \\
\hline & & & $F_{\mathrm{q}}^{\prime} / F_{\mathrm{m}}{ }^{\prime}$ & $F_{\mathrm{v}} / F_{\mathrm{m}}$ \\
\hline T1 & No treatment $(\mathrm{n}=10)$ & $F^{\prime}, F_{\mathrm{m}}^{\prime}$ & $\checkmark$ & \\
\hline $\mathrm{T} 2$ & 15 min dark adaptation $(\mathrm{n}=10)$ & $F_{0}^{15}, F_{\mathrm{m}}$ & & $\checkmark$ \\
\hline T3 & 15 min shade adaptation $(n=5)$ & $F^{\prime}, F_{\mathrm{m}}^{\prime}$ & $\checkmark$ & \\
\hline $\mathrm{T} 4$ & Shade removed, 15 min dark adaptation $(\mathrm{n}=5)$ & $F_{0}^{15}, F_{\mathrm{m}}$ & & $\checkmark$ \\
\hline T5 & 15 min light adaptation $(\mathrm{n}=5)$ & $F^{\prime}, F_{\mathrm{m}}^{\prime}$ & $\checkmark$ & \\
\hline T6 & 15 min dark adaptation $(n=5)$ & $F_{0}^{15}, F_{\mathrm{m}}$ & & $\checkmark$ \\
\hline $\mathrm{T} 7$ & 15 min light adaptation $(\mathrm{n}=5)$ & $F^{\prime}, F_{\mathrm{m}}^{\prime}$ & $\checkmark$ & \\
\hline
\end{tabular}




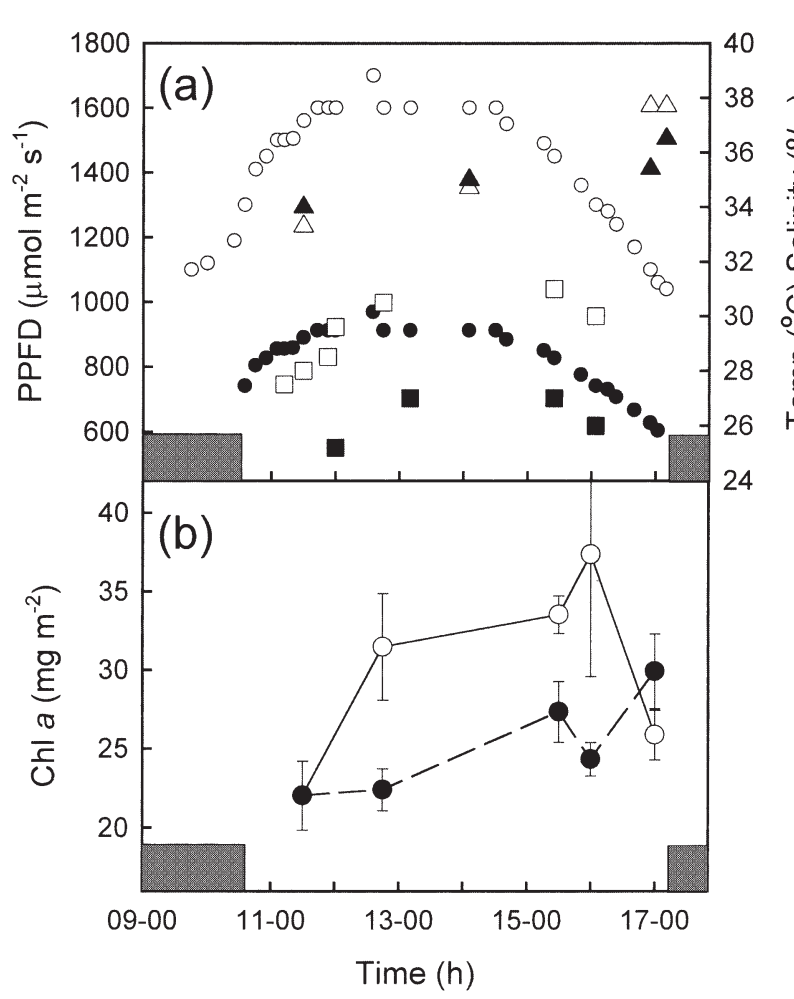

Fig. 1. (a) Light levels (photosynthetic photon flux density [PPFD]) in ambient (O) and shaded (๑) treatments, salinity in ambient $(\Delta)$ and shaded $(\boldsymbol{\Delta})$ treatments, and sediment surface temperature in ambient $(\square)$ and shaded (ם) treatments over low tide emersion. (b) Chlorophyll a ( $\mathrm{chl}$ a) concentrations in the top $2 \mathrm{~mm}$ of sediment in ambient $(\mathrm{O})$ and shaded $(\mathbf{O})$ treatments (mean $\pm \mathrm{SE}, \mathrm{n}=5)$. Solid bars indicate tidal immersion

\section{Carbohydrate fractions}

There was no significant difference between total carbohydrate and colloidal-S concentrations in the ambient light and shade treatments. Concentrations increased over the emersion period from $3739 \pm 450$ to $4869 \pm 294$ and from $357 \pm 14$ to $920 \pm 146 \mathrm{mg}$ glucose equivalent $\mathrm{m}^{-2}$ of total and colloidal-S, respectively ( $\mathrm{n}=10$, pooled data). EPS (Fig. 2a) and LMW (Fig. 2b) carbohydrate concentrations were not significantly different between treatments, with concentrations of both fractions increasing over the emersion period. The ratios of specific carbohydrate fractions to biomass (measured as chl a) did not differ significantly between ambient light and shaded treatments for colloidal-S (Fig. 3a) and LMW carbohydrate fractions (Fig. 3b) with production rates over the emersion period of 5.7 and $1.3 \mathrm{mg}$ glucose equivalent ( $\mathrm{mg} \mathrm{chl} \mathrm{a})^{-1} \mathrm{~h}^{-1}$ for colloidalS and LMW carbohydrate, respectively. Colloidal-S and LMW carbohydrate to chl a ratios did not increase linearly over the emersion period in either ambient light or shaded treatments. Both ratios increased be-

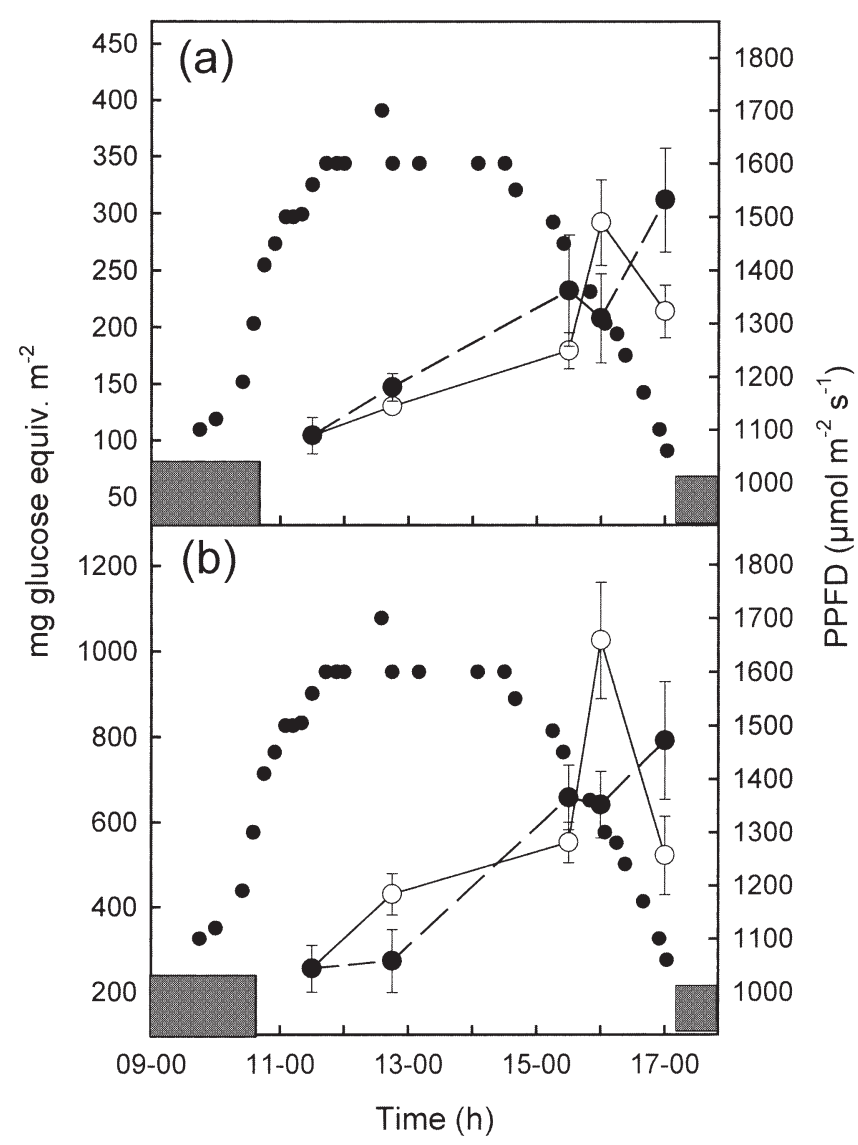

Fig. 2. (a) Extracellular polymeric substances (EPS) and (b) low molecular weight (LMW) sediment carbohydrate concentrations over low tide emersion in ambient $(O)$ and shaded $(\bullet)$ treatments with ambient PPFD $(\bullet)($ mean \pm SE, $n=5)$. Solid bars indicate tidal immersion

tween 15:40 and 16:00 h (Fig. 3a,b). EPS to chl a ratio was significantly higher in the shaded treatment $\left(F_{2(3,45)}=3.54, \mathrm{p}<0.05\right)$ than in the ambient light (Fig. 3c). EPS to chl a ratio increased linearly over the emersion period in the shaded treatment but increased in the ambient light only at 16:00 h (Fig. 3c) when PPFD had declined to $1300 \mu \mathrm{mol} \mathrm{m} \mathrm{m}^{-2} \mathrm{~s}^{-1}$ PPFD (Fig. 1a). EPS production rate calculated from concentration changes over the whole of the emersion period was higher for biofilms in the shaded treatment than for those in ambient light, with rates of 0.96 and $0.58 \mathrm{mg}$ glucose equivalent $(\mathrm{mg} \mathrm{chl} \mathrm{a})^{-1} \mathrm{~h}^{-1}$, respectively.

\section{Rates of total primary and carbohydrate production using ${ }^{14} \mathrm{C}$ radiotracer}

Total primary production rate measured by ${ }^{14} \mathrm{C}$ radiotracer at midday (Fig. 4) became saturated at around $750 \mu \mathrm{mol} \mathrm{m} \mathrm{m}^{-2} \mathrm{~s}^{-1}$ PPFD, with a maximum rate of pri- 


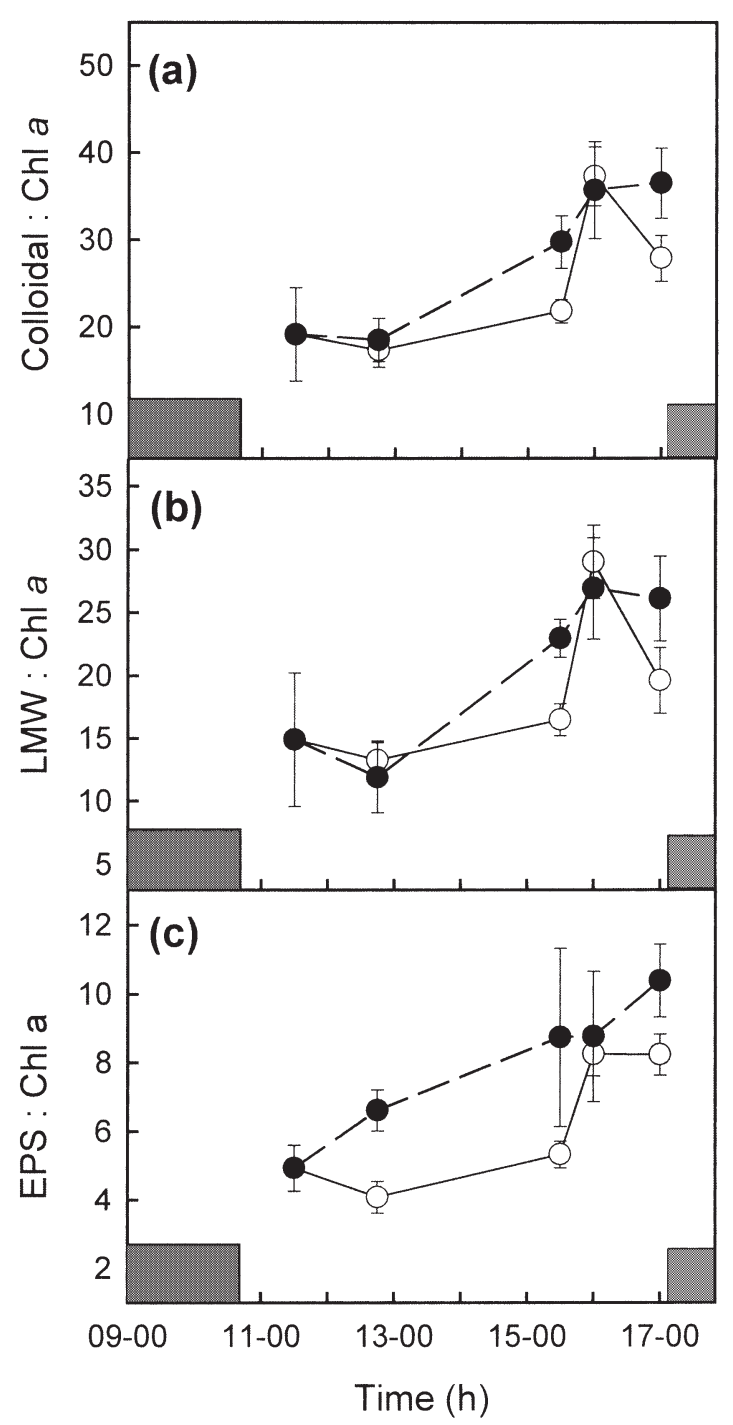

Fig. 3. (a) Colloidal-S, (b) LMW and (c) EPS carbohydrate fractions as ratios to algal biomass (chl a) over low tide emersion in ambient $(\mathrm{O})$ and shaded $(\bullet)$ treatments (mean $\pm \mathrm{SE}$, $\mathrm{n}=5$ ). Solid bars indicate tidal immersion

mary production $\left(P_{\max }\right)$ of $16 \mathrm{mg} \mathrm{C} \mathrm{m}{ }^{-2} \mathrm{~h}^{-1}$. This corresponded to a productivity $\left(P^{*}{ }_{\text {max }}\right)$ of $0.20 \mu \mathrm{g} \mathrm{C}(\mu \mathrm{g}$ $\operatorname{chl} a)^{-1} \mathrm{~h}^{-1} \cdot P_{\max }$ measured at the end of the emersion period were not significantly different between biofilms that had been exposed to ambient light and shaded treatments. However, $P_{\max }$ were significantly lower than those measured during the first incubation $\left(F_{2(3,45)}=10.21, \mathrm{p}<0.001\right)$, with a $P_{\max }$ of $5 \mathrm{mg} \mathrm{C} \mathrm{m}^{-2} \mathrm{~h}^{-1}$ at $300 \mu \mathrm{mol} \mathrm{m}^{-2} \mathrm{~s}^{-1}$ PPFD $\left(P^{*}{ }_{\text {max }}=0.06 \mu \mathrm{g} \mathrm{C}[\mu \mathrm{g} \mathrm{chl} \mathrm{a}]^{-1}\right.$ $\mathrm{h}^{-1}$ ), despite an ambient PPFD of over $1200 \mu \mathrm{mol} \mathrm{m}^{-2}$ $\mathrm{s}^{-1}$ during this period.

Colloidal-S carbohydrate production rates followed the same pattern as that of total primary production, with significantly higher $\left(F_{2(3,45)}=9.51, \mathrm{p}<0.001\right)$ rates of colloidal-S production measured at midday (Fig. 5).

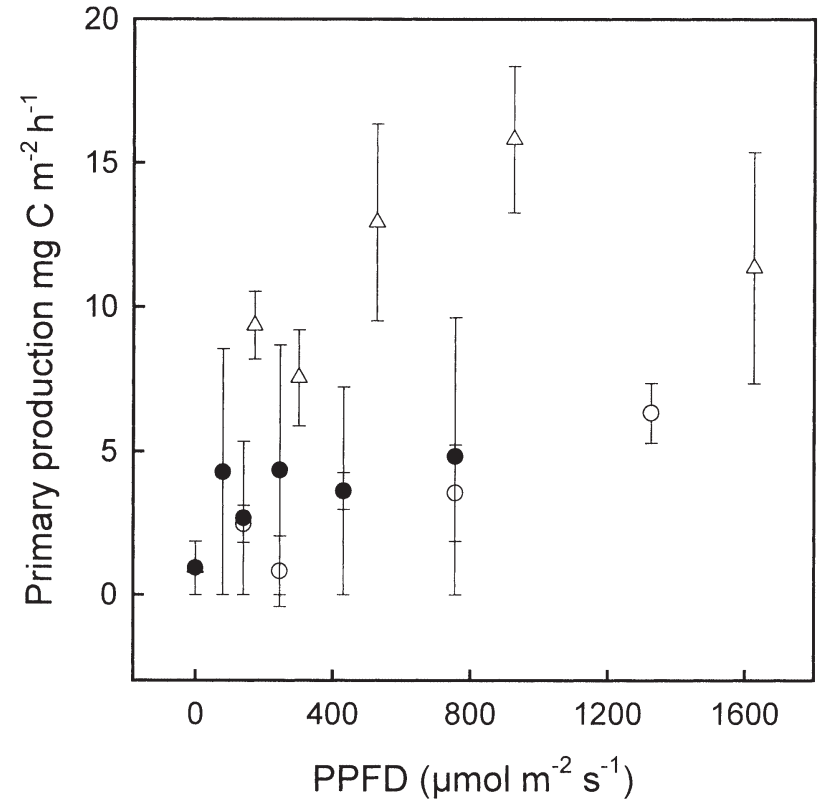

Fig. 4. Primary production rates measured by ${ }^{14} \mathrm{C}$ radiotracer at the start of emersion in ambient light $(\Delta)$, at the end of emersion in ambient light $(\mathrm{O})$, and at the end of emersion in the shaded treatment $(\bullet)($ mean $\pm \mathrm{SE}, \mathrm{n}=3$ )

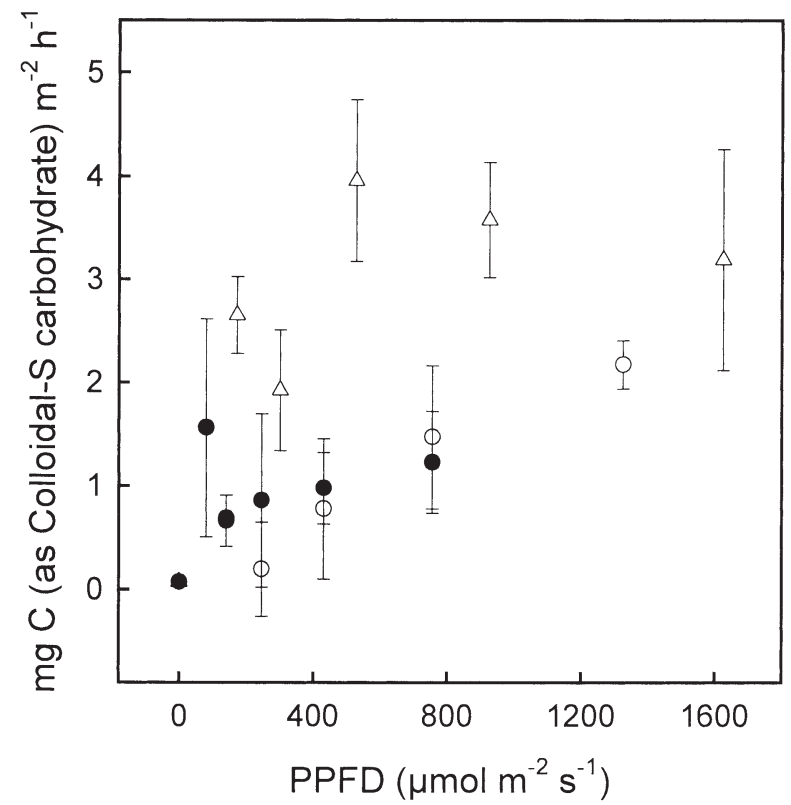

Fig. 5. Colloidal-S production rates measured by ${ }^{14} \mathrm{C}$ radiotracer at the start of emersion in ambient light $(\Delta)$, at the end of emersion in ambient light (O), and at the end of emersion in the shaded treatment $(\mathbf{O})($ mean $\pm \mathrm{SE}, \mathrm{n}=3$ )

The estimated light-saturated maximum production rate of colloidal-S carbohydrate was $3.8 \mathrm{mg} \mathrm{C} \mathrm{m}^{-2} \mathrm{~h}^{-1}$ at $600 \mu \mathrm{mol} \mathrm{m} \mathrm{m}^{-2} \mathrm{~s}^{-1}$ PPFD. Rates of colloidal-S production at the end of the emersion period were similar for biofilms that had been exposed to ambient light and 


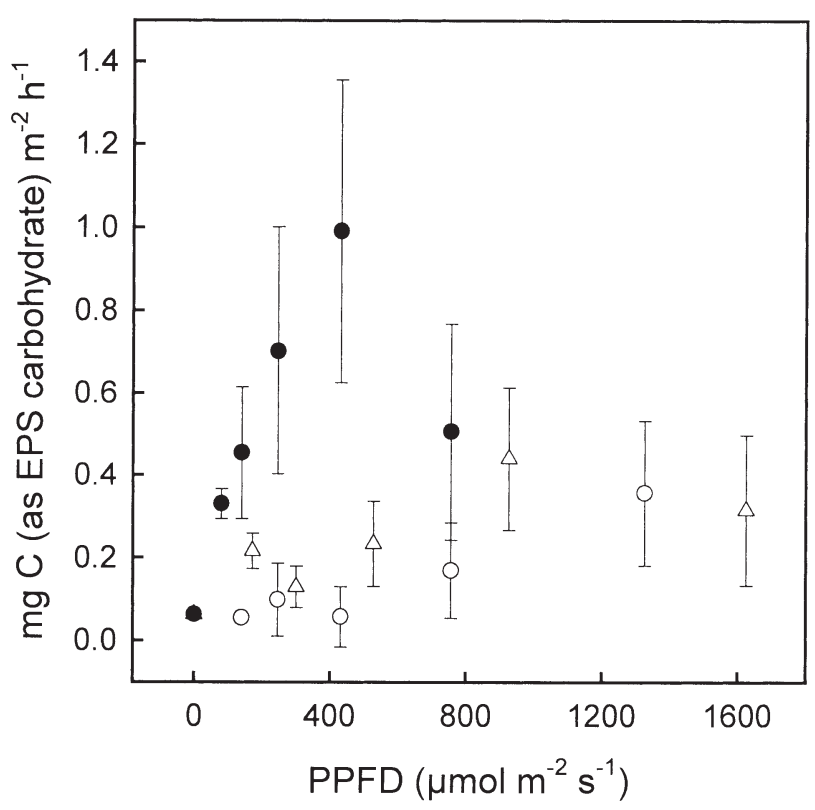

Fig. 6. EPS production rates measured by $14 \mathrm{C}$ radiotracer at the start of emersion in ambient light $(\Delta)$, at the end of emersion in ambient light $(\mathrm{O})$, and at the end of emersion in the shaded treatment $(\bullet)$ (mean $\pm \mathrm{SE}, \mathrm{n}=3$ )

shaded treatments. Estimated light-saturated maximum production rates of colloidal-S carbohydrate were 1.5 and $1.1 \mathrm{mg} \mathrm{C} \mathrm{m}{ }^{-2} \mathrm{~h}^{-1}$ in ambient light and shaded treatments, respectively.

EPS production rates were not significantly different between midday and the end of the emersion period for biofilms exposed to the ambient light (Fig. 6). Estimated light-saturated maximum EPS production rates were 0.4 and $0.3 \mathrm{mg} \mathrm{C} \mathrm{m}^{-2} \mathrm{~h}^{-1}$ in ambient light at midday and at the end of the emersion period, respectively. However, EPS production rates were significantly higher for biofilms in the shaded treatment measured at the end of the emersion period than in ambient light at both the start and end of emersion $\left(F_{2(3,45)}=13.07, \mathrm{p}<0.001\right)$, increasing linearly $(\mathrm{r}=0.98$, $\mathrm{p}<0.05, \mathrm{n}=5$ ) to $1.0 \mathrm{mg} \mathrm{C} \mathrm{m}^{-2} \mathrm{~h}^{-1}$ until $460 \mu \mathrm{mol} \mathrm{m}^{-2}$ $\mathrm{s}^{-1}$ PPFD before declining at $760 \mu \mathrm{mol} \mathrm{m} \mathrm{m}^{-2} \mathrm{~s}^{-1}$ PPFD.

The percentage allocation of photo-assimilated carbon to extracellular colloidal-S, EPS and LMW carbohydrate fractions was calculated as percentages of the
${ }^{14} \mathrm{C}$ radiotracer measurements of total primary production over the same incubation periods at the start and end of emersion (Table 2). There was no significant difference in the allocation of carbon to colloidal-S carbohydrate between the biofilms exposed to the shaded and the ambient light treatments at the end of emersion, or between biofilms in continuous ambient light at the start and at the end of the emersion period. Allocation of photo-assimilates to LMW carbohydrate, as a percentage of total primary production, was significantly higher in the ambient light than in the shaded treatment at the end of the emersion period $\left(F_{2(3,45)}=\right.$ $11.2, \mathrm{p}<0.001)$. The percentage allocation of photoassimilated carbon to EPS at the end of the emersion period was significantly higher $\left(F_{2(3,45)}=13.5, \mathrm{p}<\right.$ 0.001) for biofilms exposed to the shaded treatment than for those exposed to ambient light incubated at the start and at the end of the emersion period. This was an increase in carbon allocation to EPS as a percentage of colloidal-S carbohydrate of 11 to $61 \%$ in the shaded biofilms compared with 11 to $17 \%$ in the biofilms exposed to ambient light (Table 2).

\section{Fluorescence measurements of $F_{\mathrm{q}}{ }^{\prime} / F_{\mathrm{m}}$ ' and rel.ETR}

PSII efficiency $\left(F_{\mathrm{q}}^{\prime} / F_{\mathrm{m}}^{\prime}\right)$ was negatively correlated with irradiance $(\mathrm{r}=0.96, \mathrm{p}<0.001, \mathrm{n}=21)$ up to $740 \mu \mathrm{mol} \mathrm{m} \mathrm{m}^{-2} \mathrm{~s}^{-1}$ PPFD (Fig. 7a), and treatment and time of day had no effect on this relation. $F_{\mathrm{q}}{ }^{\prime} / F_{\mathrm{m}}{ }^{\prime}$ did not decline further above $740 \mu \mathrm{mol} \mathrm{m}{ }^{-2} \mathrm{~s}^{-1}$ PPFD. As a result rel.ETR (Fig. $7 \mathrm{~b}$ ) did not become saturated at high light, but an inflexion was observed at $750 \mu \mathrm{mol} \mathrm{m} \mathrm{m}^{-2} \mathrm{~s}^{-1}$ corresponding to a rel.ETR of 180 (relative units). $\alpha$ was calculated at 0.30 (relative units) for all data. Assuming that inflexion corresponds to

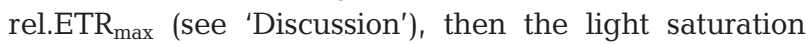
index $\left(E_{\mathrm{k}}\right)$ can be calculated as $600 \mu \mathrm{mol} \mathrm{m} \mathrm{m}^{-2} \mathrm{~s}^{-1}$.

\section{Fluorescence monitoring of vertical migration}

Ambient irradiance decreased from 1000 to $620 \mu \mathrm{mol}$ $\mathrm{m}^{-2} \mathrm{~s}^{-1}$ between the first set of measurements (T1) and the last set (T7), resulting in a slight increase in $F_{\mathrm{q}}{ }^{\prime} / F_{\mathrm{m}}{ }^{\prime}$ from 0.46 to 0.50 (Fig. 8a). This increase was

Table 2. Carbohydrate fractions measured by ${ }^{14} \mathrm{C}$ radiotracer at midday (12:00 to $12: 45 \mathrm{~h}, \mathrm{n}=30$ ) and at the end of the low tide emersion period (16:00 to $16: 45 \mathrm{~h}, \mathrm{n}=15)$. Data are means \pm SE expressed as percentage of total carbohydrate production measured for the same period of incubation

\begin{tabular}{|c|c|c|c|c|}
\hline Time/treatment & $\%$ colloidal-S & $\%$ EPS & $\%$ LMW & EPS as $\%$ of colloidal-S \\
\hline Start/ambient light & $33 \pm 4.1$ & $4 \pm 0.8$ & $30 \pm 3.7$ & $11 \pm 1.8$ \\
\hline End/ambient light & $37 \pm 5.5$ & $4.4 \pm 1.0$ & $35 \pm 4.5$ & $17 \pm 5.9$ \\
\hline End/shade adapted & $32 \pm 2.3$ & $18 \pm 3.8$ & $13 \pm 3.8$ & $61 \pm 10.2$ \\
\hline
\end{tabular}




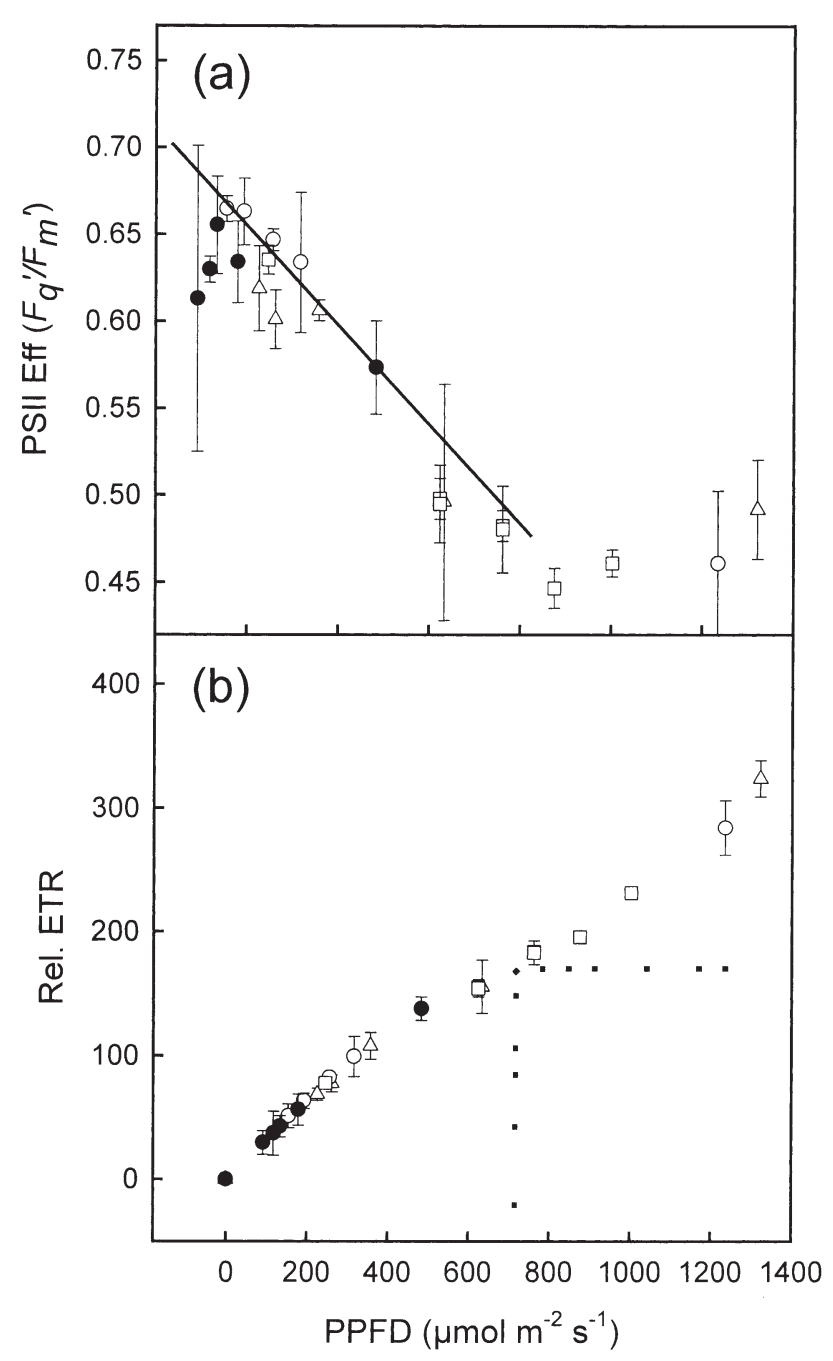

Fig. 7. (a) PSII quantum efficiency (Eff) of photochemistry $\left(F_{\mathrm{q}}^{\prime} / F_{\mathrm{m}}\right.$ ', where $F_{\mathrm{q}}^{\prime}$ is fluorescence yield of PSII quenched by photochemistry and $F_{\mathrm{m}}{ }^{\prime}$ is the maximal fluorescence in the light-adapted state) and (b) relative electron transport rate (rel.ETR) over low tide emersion for all data: at the start of emersion in ambient light $(\Delta)$, at end of emersion in ambient light $(\mathrm{O})$, at the end of emersion in the shaded treatment $(\mathbf{O})$, and the migration experiment $(\square)$ (mean $\pm \mathrm{SE}, \mathrm{n}=3$ ). The extension of the curve (dotted line) indicates a possible saturating light curve at the point of inflexion

despite an increase in $F^{\prime}$ from 195 to 262 relative units. With shading of the biofilm at T3, irradiance was reduced to 230 compared with $880 \mu \mathrm{mol} \mathrm{m}^{-2} \mathrm{~s}^{-1}$ in the ambient light. After $15 \mathrm{~min}$ in the shade, $F_{\mathrm{q}}{ }^{\prime} / F_{\mathrm{m}}{ }^{\prime}$ was significantly higher $\left(t_{8}=13.3, \mathrm{p}<0.001\right)$ than in the ambient light at 0.64 compared with $0.45 . F^{\prime}$ was also significantly higher $\left(t_{8}=3.9, \mathrm{p}<0.01\right)$ in the shade at 431 compared with 253 relative units in the ambient irradiance. $F_{\mathrm{q}}{ }^{\prime} / F_{\mathrm{m}}{ }^{\prime}$ therefore increased despite an increase in $F^{\prime}$ as irradiance decreased. After removal of

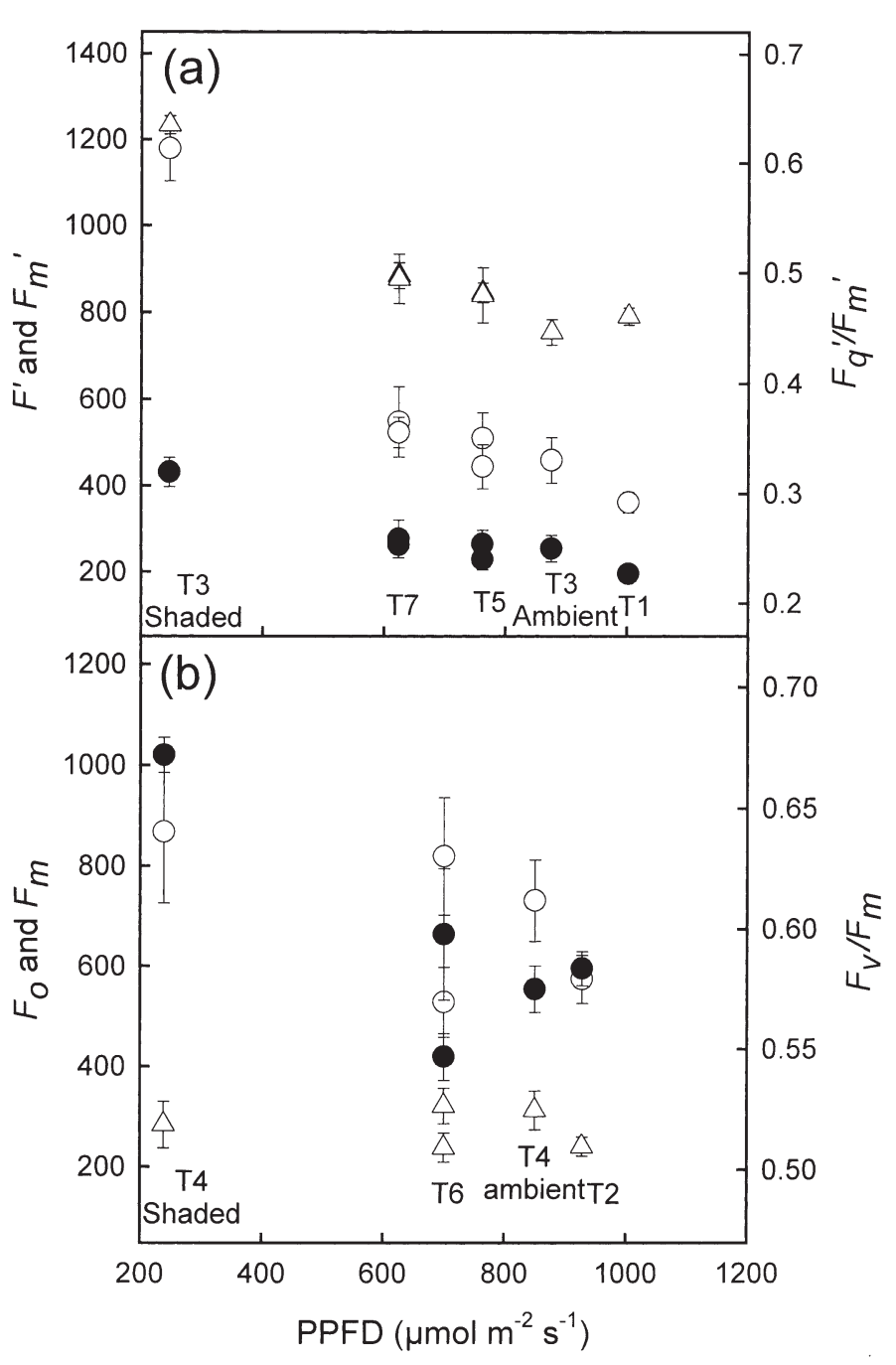

Fig. 8. (a) Light-adapted fluorescence parameters measured during the in situ migration experiment, light-adapted fluorescence just before the saturating pulse $\left(F^{\prime}\right)(\bullet), F_{\mathrm{m}}(\mathrm{O})$ and $F_{\mathrm{q}}{ }^{\prime} / F_{\mathrm{m}}{ }^{\prime}(\Delta)$. (b) Dark-adapted fluorescence measurements during the in situ migration experiment, minimal fluorescence after 15 min dark adaptation $\left(F_{0}{ }^{15}\right)(\Delta)$, maximal fluorescence in the dark-adapted state $\left(F_{\mathrm{m}}\right)(O)$ and $F_{\mathrm{v}} / F_{\mathrm{m}}$ (where $F_{\mathrm{v}}$ is variable fluorescence in the dark-adapted state and $F_{\mathrm{m}}$ is maximal fluorescence in the dark-adapted state) (๑)

the shading (T5 and T7), $F^{\prime}, F_{\mathrm{m}}{ }^{\prime}$ and $F_{\mathrm{q}}{ }^{\prime} / F_{\mathrm{m}}{ }^{\prime}$ were the same for both previously shaded biofilms and those continuously in ambient light.

Dark-adapted measurements at sampling times T2, $\mathrm{T} 4$ and $\mathrm{T} 6$ showed an increase in $F_{\mathrm{v}} / F_{\mathrm{m}}$ (where $F_{\mathrm{v}}$ is variable fluorescence in the dark-adapted state and $F_{\mathrm{m}}$ is maximal fluorescence in the dark-adapted state) due to an increase in the $F_{\mathrm{m}}$ signal with decreasing ambient light before dark adaptation (Fig. 8b). This was despite a slight increase in minimal fluorescence after $15 \mathrm{~min}$ 
dark adaptation $\left(F_{0}{ }^{15}\right)$. When the shade treatment was applied before the 15 min of dark adaptation (T4), $F_{\mathrm{v}} / F_{\mathrm{m}}$ was significantly higher $\left(\mathrm{t}_{8}=8.0, \mathrm{p}<0.001\right)$ for the biofilms in the shaded treatment $(0.67 \pm 0.007)$ than for those exposed to continuous ambient light $(0.58 \pm$ $0.007)$.

\section{DISCUSSION}

\section{Diel pattern of primary production}

Total primary production measured by ${ }^{14} \mathrm{C}$ radiotracer showed significantly higher maximum production rates in biofilms that had been exposed to ambient light at midday than in biofilms exposed to shaded or ambient light at the end of the emersion period. Although at first glance this might seem to be merely a function of light, this cannot be the case. The light levels during both periods were over $1200 \mu \mathrm{mol} \mathrm{m}^{-2} \mathrm{~s}^{-1}$ (Fig. 1), exceeding the light level $\left(750 \mu \mathrm{mol} \mathrm{m} \mathrm{m}^{-2} \mathrm{~s}^{-1}\right)$ at which the light-saturated $P_{\max }$ of $16 \mathrm{mg} \mathrm{C} \mathrm{m}^{-2} \mathrm{~h}^{-1}$ was reached at midday (Fig. 4). Secondly, rates of primary production throughout the light curve were similar in the ambient and shade treatments at the end of the emersion period despite their different light histories (Fig. 4). This indicates a light-independent decrease in the rate of production over the emersion period. Carbon sequestering may be highest at the start of emersion until carbon limitation, other nutrient limitation (Miles \& Sundbäck 2000) in the biofilm or the buildup of photo-assimilates inhibits further carbon uptake. This pattern of late emersion phase decrease has also been measured in the temperate Colne estuary, Essex, UK (Perkins et al. in press). Miles \& Sundbäck (2000) reported changes in primary production across the emersion period for the same site (Sarilhos Pequenos), with no relation observed between primary production and irradiance. Although they reported a lack of a consistent trend in primary production over the emersion period, examination of their Fig. 2c shows the same pattern in primary production on 25 June as observed in this study in July. In addition they reported a mean rate of primary production of $11 \mathrm{mg} \mathrm{C} \mathrm{m}^{-2} \mathrm{~h}^{-1}$, similar to the estimated $P_{\max }$ of $16 \mathrm{mg} \mathrm{C} \mathrm{m}^{-2} \mathrm{~h}^{-1}$ reported in this study. In contrast, Serôdio \& Catarino (2000) predicted an increase in primary production at the start of emersion or after the onset of daylight, followed by a decline before immersion or night. Their data were calculated from $P_{\max }$ and $\alpha$ and biomass changes were estimated from temporal variations in $F_{0}$ measurements, a method that has inherent problems (see below). However, their data showed significant hourly variation in primary production based on irradiance and migration-induced changes in biomass.

\section{Relative ETR and vertical migration}

There was a close agreement between the ${ }^{14} \mathrm{C}$ (Fig. 4) and PAM fluorescence measurements (Fig. 7) indicating light saturation of primary production at approximately $750 \mu$ mols $\mathrm{m}^{-2} \mathrm{~s}^{-1}$. Primary production rate was light saturated at $750 \mu \mathrm{mol} \mathrm{m} \mathrm{m}^{-2} \mathrm{~s}^{-1}$ at midday. This light level is close to that $\left(740 \mu \mathrm{mol} \mathrm{m} \mathrm{m}^{-2} \mathrm{~s}^{-1}\right)$ at which $F_{\mathrm{q}}{ }^{\prime} / F_{\mathrm{m}}^{\prime}$ reached a minimum with no further decline (Fig. 7a). However, between 700 and $800 \mu \mathrm{mol}$ $\mathrm{m}^{-2} \mathrm{~s}^{-1}$ PPFD, an inflexion is present on the light response curve (Fig. $7 \mathrm{~b}$ ). The point of inflexion may indicate the true rel.ETR $\mathrm{max}_{\text {ax }}$ of the biofilms. After this inflexion point, rel.ETR began to increase. This further increase in rel.ETR can be attributed to downward vertical migration exposing the diatoms to a lower light environment in the sediment, resulting in higher values of $F_{\mathrm{q}}{ }^{\prime} / F_{\mathrm{m}}{ }^{\prime}$ than would have been expected at the incident surface light level recorded. Vertical migration into sediments appears to be a form of behavioural photo-acclimation to avoid high light-induced photodamage (Kromkamp et al. 1998, Paterson et al. 1998, Perkins et al. in press, G.J.C.U. unpubl. data). This highlights a difficulty in using in situ fluorescence to measure ETR in intact biofilms. Vertical migration can result in an over-estimation of rel.ETR and the light curve may not become saturated (Perkins et al. in press). This error results in a lack of correlation between ${ }^{14} \mathrm{C}$ primary production rates and PAM fluorescence measurements of rel.ETR once $E_{\mathrm{k}}$ has been exceeded (Barranguet \& Kromkamp 2000).

The presence of light-induced migration was also shown by the fluorescence measurements made on 12 July at the same sample site. As ambient light decreased, an increase in $F_{\mathrm{q}}{ }^{\prime} / F_{\mathrm{m}}{ }^{\prime}$ was observed (Fig. 8a). With decreasing light, non-photochemical quenching would decrease (resulting in an increase in $F_{m}{ }^{\prime}$ ) and the $\mathrm{Q}_{\mathrm{A}}$ (primary electron acceptor in PS II) pool would become more oxidised (observed as a decrease in $F^{\prime}$ ). $F_{\mathrm{q}}{ }^{\prime} / F_{\mathrm{m}}{ }^{\prime}$ increased despite an increase in the $F^{\prime}$ signal. This increase in $F^{\prime}$ is attributed to an increase in surface biomass due to migration of diatoms towards the sediment surface. When biofilms were shaded, a further increase in $F_{\mathrm{q}}{ }^{\prime} / F_{\mathrm{m}}{ }^{\prime}$ was measured, with a $70 \%$ higher $F^{\prime}$ signal compared with biofilms remaining in ambient light. Removal of shading returned both $F_{\mathrm{q}}{ }^{\prime} / F_{\mathrm{m}}{ }^{\prime}$ and $F^{\prime}$ to values similar to those of biofilms that had not been shaded. Migrational response to changes in light level were therefore rapid (within $15 \mathrm{~min}$ ) and occurred both towards and away from the sediment surface with decreasing and increasing light level, respectively.

Migration was also evident from dark-adapted fluorescence measurements (Fig. 8b) indicating that light history was important in determining the fluorescence yield at both $F_{0}{ }^{15}$ and $F_{\mathrm{m}}$. As ambient light levels 
decreased, there was a slight increase in $F_{0}{ }^{15}$, indicating migration of cells to the sediment surface. Dark adaptation then acted to oxidise $\mathrm{Q}_{\mathrm{A}}$ and reverse nonphotochemical quenching (observed as an increase in $F_{\mathrm{m}}$ ). Fifteen minutes of dark adaptation was not long enough to obtain a true $F_{\mathrm{v}} / F_{\mathrm{m}}$ for these biofilms, as shaded biofilms (T4) had significantly higher $F_{\mathrm{v}} / F_{\mathrm{m}}$ than biofilms in ambient light, due to a higher value of $F_{m}$. These processes make in situ dark-adapted fluorescence measurements on intact biofilms difficult to interpret.

\section{Carbohydrate production patterns}

Total colloidal exudate production (Fig. 5) was closely linked to the rate of net primary production (Smith \& Underwood 1998, Staats et al. 2000), with colloidal-S production rates $\left({ }^{14} \mathrm{C}\right)$ higher at midday and with no significant difference between shaded and non-shaded biofilms at the end of the emersion period. Though rates of colloidal-S production varied with light (mirroring primary production), the proportional allocation of photo-assimilates into colloidal-S remained constant (Table 2). The percentage allocation values (32 to $37 \%$ ) were substantially higher than data from in situ labelling (8 to $10.9 \%$ ) carried out in the Humber estuary, UK, where maximum irradiances were $\sim 620 \mu \mathrm{mol} \mathrm{m} \mathrm{m}^{-2} \mathrm{~s}^{-1}$ (Smith \& Underwood 1998). High irradiances can lead to 'overflow' of photoassimilates into the sediments (Staats et al. 2000), particularly when nutrients become limiting, and substantially higher ratios of colloidal carbohydrate to chl a have been measured in tropical microphytobenthic biofilms (G.J.C.U. unpubl. data). In axenic diatom cultures exposed to nutrient limitation, up to $62 \%$ of photo-assimilates can be excreted into colloidal-S within $4 \mathrm{~h}$ of incubation (Smith \& Underwood 1998, 2000).

There were clear treatment effects on the production of high (EPS) and LMW carbohydrates within the colloidal-S fraction. EPS production rates $\left({ }^{14} \mathrm{C}\right.$, Fig. 6) and percentage allocation of photoassimilates (Table 2) were highest in the 'shaded' biofilms at the end of the emersion period $\left(1.0 \mathrm{mg} \mathrm{C} \mathrm{m} \mathrm{m}^{-2} \mathrm{~h}^{-1}, 18 \%\right.$, respectively) compared with non-shaded biofilms (0.3 mg C $\mathrm{m}^{-2} \mathrm{~h}^{-1}, 4 \%$, respectively). The increase in the EPS to chl a ratio (Fig. 3) was also highest in the shade treatment, with a linear increase in EPS to chl a during the emersion period. This increased allocation of photo-assimilates into EPS under low light conditions and increased EPS production in darkened conditions has been seen in sediments and cultures (Smith \& Underwood 1998, 2000, van Duyl et al. 1999). Benthic diatoms produce EPS during locomotion and during periods of unbalanced growth (Sutherland et al. 1998, de Winder et al. 1999, Smith \& Underwood 2000, Staats et al. 2000). Staats et al. (2000) concluded that oxygenic photosynthesis is a prerequisite for extracellular carbohydrate production, with production positively related to light and light dose, leading to unbalanced growth and 'overflow' of excess photoassimilates. While we agree that 'overflow' does occur (G.J.C.U. unpubl. data), the data presented here of higher rates of EPS production in lower than in higher irradiance conditions strongly suggests that increased EPS production is not exclusively a direct, light-mediated response. Not only are cells allocating proportionally more photo-assimilates to EPS production, the actual rates of EPS production were higher in shaded than in ambient treatments when incubated at the same PPFD. One possible explanation is that at lower light levels, motility (and hence EPS production) increased as the diatom cells are stimulated to try to find higher light conditions to maximise photosynthesis. While this may explain changes in concentrations over the emersion period, it does not explain why, when incubated at the same PPFD, the shade-treated biofilms produced more EPS. A second hypothesis is that at higher light, increasing intracellular concentrations of photo-assimilates may inhibit carbon allocation to EPS and increase LMW carbohydrate production and excretion instead. This effect would have to be strong enough to last during the pre-incubation and incubation periods of the ${ }^{14} \mathrm{C}$ measurements. These hypotheses remain to be tested.

There was little change in the carbohydrate to chl a ratios in the ambient light treatments, until later in the emersion period (Fig. 3) when irradiance had decreased below $1300 \mu \mathrm{mol} \mathrm{m} \mathrm{m}^{-2} \mathrm{~s}^{-1}$ (Fig. 1). This is contrary to that observed in some other studies, where carbohydrate to chl a ratios tend to increase over the emersion period (Underwood \& Smith 1998, van Duyl et al. 1999, 2000). This may be due to diatoms migrating away from the surface layers during the midday period to avoid high light or temperature conditions (Blanchard et al. 1996), thereby reducing the rate of primary production and carbohydrate excretion. This would be supported by the migration data, where photoacclimatory-migration was induced above about $750 \mu \mathrm{mol} \mathrm{m} \mathrm{m}^{-2} \mathrm{~s}^{-1}$. Increases in the colloidal-S chl $a_{\text {, }}$ LMW carbohydrate to chl $a$ and EPS to chl a ratios later in the emersion period could have been due to increased photosynthesis as cells returned to the surface, in combination with the endogenous increase in extracellular carbohydrate production known to occur in epipelic biofilms just before tidal cover (Smith \& Underwood 1998, Taylor et al. 1999, G.J.C.U. unpubl. data). 


\section{Conclusions}

This study has shown that there was a reduction in $P_{\max }$ in the diatom biofilms over the emersion period that was not a function of either the incident light or the light history of the biofilms. Primary production did not correlate with measurements of in situ ETR, due in part to the light-induced migration of the cells away from the sediment surface during periods of high irradiance. Downward migration coincided with the light level at which $P_{\max }\left({ }^{14} \mathrm{C}\right.$ measurements) was reached also with the point of inflexion on the ETR versus PPFD curve. Above this light level, ETR continued to increase (i.e., overestimation of values due to migration) but primary production was light saturated. Though shading did not affect total primary production, it did significantly increase EPS production rate and percentage allocation of photoassimilates into EPS. In contrast, percentage allocation of photo-assimilates to LMW extracellular carbohydrate was higher in the non-shaded treatments, probably due to photosynthetic 'overflow'. In non-shaded biofilms there was little or no increase in the concentration of all extracellular carbohydrate fractions until the last hour before tidal immersion. High light levels during the course of the emersion period induced downward migration of microphytobenthos. This reduction in surface-active biomass resulted in little net production of EPS and LMW carbohydrates until the end of the emersion period. These effects, coupled with a light-independent reduction in the rate of primary production, caused a deviation from the diel pattern expected if microphytobenthic biofilm activity were primarily light driven.

Acknowledgements. This work was supported by NERC Grant GR3/11872 (R.G.P.), Commonwealth Scholarship Commission in the UK, ZACN-1999-36 (G.C.S.), Instituto de Cooperaçâo cientifica e Technologica Internacional (G.J.C.U.) and the British Council (G.J.C.U.). Thanks to Paulo Cataxana for technical assistance.

\section{LITERATURE CITED}

Barranguet C, Kromkamp J (2000) Estimating primary production rates from photosynthetic electron transport in estuarine microphytobenthos. Mar Ecol Prog Ser 204: 39-52

Blanchard GF, Guarini JM (1999) Temperature effects on microphytobenthic productivity in temperate, intertidal mudflats. Vie Milieu 48:271-284

Blanchard GH, Guarini JM, Richard P, Gros P, Mornet F (1996) Quantifying the short-term temperature effect on light-saturated photosynthesis of intertidal microphytobenthos. Mar Ecol Prog Ser 134:309-313

Brotas V, Catarino F (1995) Microphytobenthos primary production of Tagus estuary intertidal flats (Portugal). Neth J Aquat Ecol 29:333-339
Brotas V, Plante-Cuny MR (1998) Spatial and temporal patterns of microphytobenthic taxa of estuarine tidal flats in the Tagus Estuary (Portugal) using pigment analysis by HPLC. Mar Ecol Prog Ser 171:43-57

Decho AW (1990) Microbial exopolymer secretions in ocean environments. Their role(s) in foodwebs and marine processes. Oceanogr Mar Biol Annu Rev 28:73-153

de Winder B, Staats N, Stal LJ, Paterson DM (1999) Carbohydrate secretion by phototrophic communities in tidal sediments. J Sea Res 42:131-146

Dubois M, Gilles KA, Hamilton JK, Rebers PA, Smith F (1956) Colorimetric method for determination of sugars and related substances. Anal Chem 28:350-356

Genty B, Briantais JM, Baker NR (1989) The relationship between the quantum yield of photosynthetic electron transport and quenching of chlorophyll fluorescence. Biochim Biophys Acta 990:87-92

Guarini JM, Blanchard GF, Gros P, Harrison SJ (1997) Modelling the mud surface temperature on intertidal flats to investigate the spatio-temporal dynamics of the benthic microalgal photosynthetic capacity. Mar Ecol Prog Ser 153:25-36

Hartig P, Wolfstein K, Lippenmeier S, Colijn F (1998) Photosynthetic activity of natural microphytobenthos populations measured by fluorescence (PAM) and ${ }^{14} \mathrm{C}$-tracer methods: a comparison. Mar Ecol Prog Ser 166:53-62

Hoagland KD, Rosowski JR, Gretz MR, Roemer SC (1993) Diatom extracellular polymeric substances: function, fine structure, chemistry and physiology. J Phycol 29:537-566

Kromkamp J, Barranguet C, Peene J (1998) Determination of microphytobenthos PSII quantum efficiency and photosynthetic activity by means of variable chlorophyll fluorescence. Mar Ecol Prog Ser 162:45-55

Long SP, Hällgren JE (1993) Measurement of $\mathrm{CO}_{2}$ assimilation by plants in the field and laboratory. In: Hall DO, Scurlock JMO, Bothar-Nordenkamps HR, Leegood RC, Long SP (eds) Photosynthesis and production in a changing environment, a field and laboratory manual. Chapman and Hall, London, 1-464

Lorenzen GJ (1967) Determination of chlorophyll and phaeopigments: spectrophotometric equations. Limnol Oceanogr 12:343-346

Middleburg JJ, Barranguet C, Boschker HTS, Herman PMJ, Moens T, Heip CHR (2000) The fate of intertidal microphytobenthos carbon: an in situ ${ }^{13} \mathrm{C}$-labelling study. Limnol Oceanogr 45:1224-1234

Miles A, Sundbäck K (2000) Diel variation in microphytobenthic productivity in areas of different tidal amplitude. Mar Ecol Prog Ser 205:11-22

Oxborough K, Hanlon ARM, Underwood GJC, Baker NR (2000) In vivo estimation of the photosystem II photochemical efficiency of individual microphytobenthic cells using high-resolution imaging of chlorophyll a fluorescence. Limnol Oceanogr 45:1420-1425

Paterson DM (1994) Microbiological mediation of sediment structure and behaviour. In: Stal LJ, Caumette P (eds) Microbial mats. NATO ASI series, Vol G35. Springer Verlag, Berlin, p 97-109

Paterson DM, Wiltshire KH, Miles A, Blackburn J, Davidson I, Yates MG, McGroty S, Eastwood JA (1998) Microbiological mediation of spectral reflectance from intertidal cohesive sediments. Limnol Oceanogr 43:1027-1221

Perkins RG, Oxborough K, Hanlon ARM, Underwood GJC, Baker NR (in press) Can chlorophyll fluorescence be used to estimate the rate of photosynthetic electron transport within microphytobenthic biofilms? Mar Ecol Prog Ser

Sakshaug E, Bricaud A, Dandonneau Y, Falkowski PG, Keifer 
DA, Legendre L, Morel A, Parslow J, Takahashi M (1997) Parameters of photosynthesis: definitions, theory and interpretations of results. J Plankton Res 19:1637-1670

Serôdio J, Catarino F (2000) Modelling the primary productivity of intertidal microphytobenthos: time scales of variability and effects of migratory rhythms. Mar Ecol Prog Ser 192:13-30

Serôdio J, da Silva JM, Catarino F (1997) Non-destructive tracing of migratory rhythms of intertidal benthic microalgae using in vivo chlorophyll a fluorescence. J Phycol 33: 542-553

Smith DJ, Underwood GJC (1998) Exoploymer production by intertidal epipelic diatoms. Limnol Oceanogr 43: 1578-1591

Smith DJ, Underwood GJC (2000) The production of extracellular carbohydrate exopolymers (EPS) by estuarine benthic diatoms: the effects of growth phase and light and dark treatment. J Phycol 36:321-333

Staats N, Stal LJ, de Winder B, Mur LR (2000) Oxygenic photosynthesis as driving process in exopolysaccharide production of benthic diatoms. Mar Ecol Prog Ser 193: 261-269

Sutherland TF, Grant J, Amos CL (1998) The effect of carbohydrate production by the diatom Nizschia curvilineata on the erodibility of sediment. Limnol Oceanogr 43:65-72

Taylor IS, Paterson DM, Mehlert A (1999) The quantitative

Editorial responsibility: Otto Kinne (Editor),

Oldendorf/Luhe, Germany variability and monosaccharide composition of sediment carbohydrates associated with intertidal diatom assemblages. Biogeochemistry 45:303-327

Underwood GJC, Smith DJ (1998) Predicting epipelic diatom exopolymer concentrations in intertidal sediments from sediment chl a. Microb Ecol 35:116-125

Underwood GJC, Kromkamp J (1999) Primary production by phytoplankton and microphytobenthos in estuaries. Adv Ecol Res 29:93-153

Underwood GJC, Paterson DM, Parkes RJ (1995) The measurement of microbial carbohydrate exoploymers from intertidal sediments. Limnol Oceanogr 40:1243-1253

Underwood GJC, Nilsson C, Sundbäck K, Wulff A (1999) Short-term effects of UVB radiation on chlorophyll fluorescence, biomass, pigments and carbohydrate fractions in a benthic diatom mat. J Phycol 35:656-666

van Duyl FC, de Winder B, Kop AJ, Wollenzien U (1999) Tidal coupling between carbohydrate concentrations and bacterial activities in diatom-inhabited intertidal mudflats. Mar Ecol Prog Ser 191:19-32

Widdows J, Brown S, Brinsley MD, Salkeld PN, Elliott M (2000) Temporal changes in intertidal sediment erodability: influence of biological and climatic factors. Cont Shelf Res 20:1275-1289

Zar JH (1996) Biostatistical analysis, 3rd edn. Prentice Hall Inc, Upper Saddle River, NJ

Submitted: February 12, 2001; Accepted: May 14, 2001

Proofs received from author(s): November 12, 2001 